\title{
Synthesis of the Spirocyclic Core of the Prunolides Using a Singlet Oxygen-Mediated Cascade Sequence.
}

Nikoletta Sofikiti, Maria Tofi, Tamsyn Montagnon, Georgios Vassilikogiannakis, ${ }^{*}$ Manolis Stratakis. ${ }^{*}$

Department of Chemistry, University of Crete, 71409 Iraklion, Crete, Greece.

Emai:vasil@chemistry.uoc.gr, stratakis@chemistry.uoc.gr

\section{Contents:}

(1) Experimental procedures for synthesis of $6 a / b, 8 a / b, 9$, and 10

(2) Copies of Relevant Spectra for 6a, 6b, 8a, 8b, 9, and 10 


\section{(1) Experimental procedures for the synthesis of $6 a / b, 8 a / b, 9$, and 10}

General techniques: Diethyl ether and THF were distilled from Na/benzophenone. Reagents were purchased at the highest commercial quality and used without further purification. Irradiation experiments (photooxygenations) were performed with a xenon Variac Eimac Cermax $300 \mathrm{~W}$ lamp. Reactions were monitored by thin-layer chromatogaphy (TLC) carried out on silica gel plates (60F-254) using UV light as visualizing agent and an acidic mixture of phosphomolybdic acid/cerium(iv) sulfate and heat as developing agents. This solution contains $94 \mathrm{~mL} \mathrm{H}_{2} \mathrm{O}, 6 \mathrm{~mL}$ concentrated $\mathrm{H}_{2} \mathrm{SO}_{4}, 1.0 \mathrm{~g} \mathrm{Ce}\left(\mathrm{SO}_{4}\right)_{2} \cdot\left(\mathrm{H}_{2} \mathrm{O}\right)_{\mathrm{n}}$ and $1.5 \mathrm{~g}$ phosphomolybdic acid. Chromatogaphy refers to flash chromatogaphy and was carried out on $\mathrm{SiO}_{2}$ (silica gel 60, particle size $0.040-0.063 \mathrm{~mm})$.

NMR spectra were recorded on Bruker AMX-500 instrument and calibrated using residual undeuterated solvent as an internal reference. The following abbreviations were used to explain the multiplicities: $\mathrm{s}=$ singlet, $\mathrm{d}=$ doublet, $\mathrm{t}=$ triplet, $\mathrm{q}=$ quartet, $\mathrm{m}=$ multiplet, $\mathrm{br}=$ broad. Electrospray ionization mass spectrometry (ESIMS) experiments were performed on an API 100 Perkin - Elmer SCIEX single quadrupole mass spectrometer at $4000 \mathrm{~V}$ emitter voltage. High resolution mass spectra (HRMS) were recorded on an Agilent mass spectrometer under ESI-TOF (time of flight) high accuracy conditions.

\section{$N, 4$-Dimethoxy- $N$-methylbenzamide (10)}

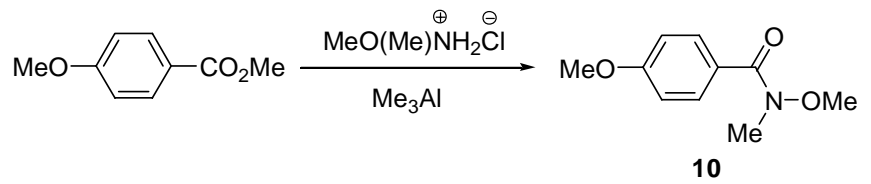

To a flame dried flask under an inert argon atmosphere was added $\mathrm{N}, \mathrm{O}$ dimethylhydroxylamine hydrochloride (2.93 g, $30 \mathrm{mmols})$ in $\mathrm{CH}_{2} \mathrm{Cl}_{2}(50 \mathrm{~mL})$. The solution was cooled to $0{ }^{\circ} \mathrm{C}$ and trimethylaluminum $(15.0 \mathrm{~mL}, 2 \mathrm{M}$ in toluene, $30 \mathrm{mmol})$ was then added dropwise. After 30 min stirring, methyl 4-methoxy benzoate (2.5 g, 15 mmols) was added to the reaction mixture at $25{ }^{\circ} \mathrm{C}$ which was then left to stir for $48 \mathrm{~h}$. The reaction was quenched with $5 \%$ $\mathrm{HCl}$ that was added until bubbling ceased. The organic layer was washed with brine $(80 \mathrm{~mL})$, dried $\left(\mathrm{MgSO}_{4}\right)$ and then concentrated in vacuo. The oily residue was purified by flash column 
chromatography (silica gel, hexane:ethyl acetate $=2: 1)$ to afford $\mathbf{1 0}\left(2.51 \mathrm{~g}, 85 \%\right.$ yield). ${ }^{1} \mathrm{H}$ $\operatorname{NMR}\left(500 \mathrm{MHz}, \mathrm{CDCl}_{3}\right): \delta=7.74(\mathrm{~d}, J=8.5 \mathrm{~Hz}, 2 \mathrm{H}), 6.91(\mathrm{~d}, J=8.5 \mathrm{~Hz}, 2 \mathrm{H}), 3.85(\mathrm{~s}, 3 \mathrm{H})$, $3.57(\mathrm{~s}, 3 \mathrm{H}), 3.36(\mathrm{~s}, 3 \mathrm{H}) \mathrm{ppm} .{ }^{13} \mathrm{C}$ NMR $\left(125 \mathrm{MHz}, \mathrm{CDCl}_{3}\right): \delta=168.9,161.1,130.1,125.6$, $112.8,60.4,54.8,33.4 \mathrm{ppm}$.

\section{Aryl ketone 9}

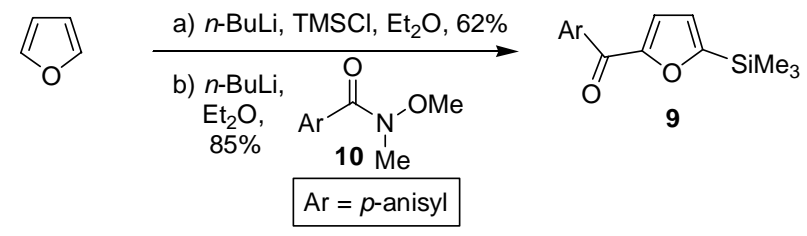

To a flame dried flask, under an inert argon atmosphere at $25^{\circ} \mathrm{C}$, was added furan $(1.0 \mathrm{~g}, 14.7$ mmols) in anhydrous diethyl ether ( $25 \mathrm{~mL}) . n$-BuLi (9.2 mL, $1.6 \mathrm{M}$ in hexanes, $14.7 \mathrm{mmols})$ was added and the reaction heated to reflux for $3 \mathrm{~h}$. After cooling to $0{ }^{\circ} \mathrm{C}$, trimethylsilyl chloride $(0.9$ $\mathrm{mL}, 14.0 \mathrm{mmols}$ ) was added dropwise and the resulting mixture stirred for $1 \mathrm{~h}$ at $25{ }^{\circ} \mathrm{C}$ before being quenched with water $(20 \mathrm{~mL})$. The layers were separated and the organic layer washed with brine $(30 \mathrm{~mL})$ and dried $\left(\mathrm{MgSO}_{4}\right)$. Trimethylsilylfuran $(1.27 \mathrm{~g}, 62 \%)$ was collected by careful distillation of the organic solution.

To a flame dried flask, under an inert argon atmosphere at $25^{\circ} \mathrm{C}$, was added trimethylsilylfuran $(0.5 \mathrm{~g}, 3.57 \mathrm{mmols}$, see above for preparation) in anhydrous diethyl ether (15 mL). $n$-BuLi (2.3 $\mathrm{mL}, 1.6 \mathrm{M}$ in hexanes, $3.7 \mathrm{mmols}$ ) was added and the reaction heated to reflux for $3 \mathrm{~h}$. The mixture was cooled to $0{ }^{\circ} \mathrm{C}$ and the Weinreb amide $10(0.65 \mathrm{~g}, 3.3 \mathrm{mmols})$ was added. The reaction was then stirred at $25{ }^{\circ} \mathrm{C}$ overnight before being quenched with water $(15 \mathrm{~mL})$. The layers were separated and the organic layer washed with brine $(15 \mathrm{~mL})$, dried $\left(\mathrm{MgSO}_{4}\right)$, and concentrated in vacuo. The residue was purified by flash column chromatography (silica gel, hexane:ethyl acetate $=4: 1)$ to afford $9(0.83 \mathrm{~g}, 85 \%)$. ${ }^{1} \mathrm{H} \mathrm{NMR}\left(500 \mathrm{MHz}, \mathrm{CDCl}_{3}\right): \delta=8.07(\mathrm{~d}, J$ $=8.5 \mathrm{~Hz}, 2 \mathrm{H}), 7.22(\mathrm{~d}, J=3.5 \mathrm{~Hz}, 1 \mathrm{H}), 6.99(\mathrm{~d}, J=8.5 \mathrm{~Hz}, 2 \mathrm{H}), 6.75(\mathrm{~d}, J=3.5 \mathrm{~Hz}, 1 \mathrm{H}), 3.90$ (s, $3 \mathrm{H}), 0.36$ (s, $9 \mathrm{H}) \mathrm{ppm} .{ }^{13} \mathrm{C}$ NMR $\left(125 \mathrm{MHz}, \mathrm{CDCl}_{3}\right): \delta=181.1,166.3,163.1,156.5,131.7$, 130.2, 121.1, 119.4, 113.6, 55.4, -1.9 ppm.

\section{1,2-difuryl alkenes 8a and $8 b$}




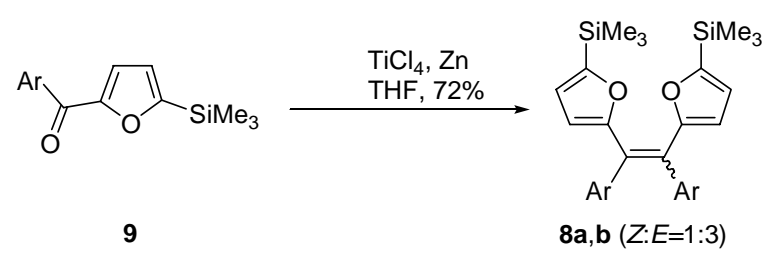

To a flame dried flask, under an inert argon atmosphere at $25^{\circ} \mathrm{C}$, was added $\mathrm{Zn}$ dust $(0.94 \mathrm{~g}, 14.4$ mmols), anhydrous THF (20 mL), and $\mathrm{TiCl}_{4}(0.8 \mathrm{~mL}, 7.2 \mathrm{mmols})$ in the same order as listed. The resulting slurry was heated to reflux for $3 \mathrm{~h}$. The color turned black over this period. Aryl ketone $9(0.65 \mathrm{~g}, 2.37 \mathrm{mmols})$ was added and the reaction mixture heated to reflux for $40 \mathrm{mins}$, at which complete consumption of the aryl ketone 9 was observed by TLC. The volume was reduced in vacuo to approximately $2 \mathrm{~mL}$ and diethyl ether $(20 \mathrm{~mL}$ ) added. The organic solution was then washed with sat. aq. $\mathrm{NaHCO}_{3}(20 \mathrm{~mL})$, dried $\left(\mathrm{MgSO}_{4}\right)$, and concentrated in vacuo. The resulting yellow solid residue $(0.44 \mathrm{~g}, 72 \%)$ was a mixture $8 \mathbf{a}$ and $\mathbf{8 b}$ without significant quantities of any by-product. The isomeric mixture (8a and $\mathbf{b}$ ) was separated by flash column chromatography (silica gel, hexane:ethyl acetate $=25: 1)$. 8b: less polar isomer, ${ }^{1} \mathrm{H}$ NMR $\left(500 \mathrm{MHz}, \mathrm{CDCl}_{3}\right): \delta=$ $7.24(\mathrm{~d}, J=8.5 \mathrm{~Hz}, 4 \mathrm{H}), 6.85$ (d, $J=8.5 \mathrm{~Hz}, 4 \mathrm{H}), 6.43$ (d, $J=3.5 \mathrm{~Hz}, 2 \mathrm{H}), 5.82(\mathrm{~d}, J=3.5 \mathrm{~Hz}$, $2 \mathrm{H}), 3.77$ (s, $6 \mathrm{H}), 0.01$ (s, $18 \mathrm{H}) \mathrm{ppm} .{ }^{13} \mathrm{C} \mathrm{NMR}\left(125 \mathrm{MHz}, \mathrm{CDCl}_{3}\right): \delta=160.1,159.8,158.6$, 134.4, 131.6, 127.6, 120.5, 113.2, 112.6, 55.1, -2.1 ppm. HRMS (ESI-TOF): calcd for $\mathrm{C}_{30} \mathrm{H}_{37} \mathrm{O}_{4} \mathrm{Si}_{2}: 517.2225[\mathrm{M}+\mathrm{H}]^{+}$; found 517.2217. 8a: more polar isomer, ${ }^{1} \mathrm{H}$ NMR (500 MHz, $\left.\mathrm{CDCl}_{3}\right): \delta=7.04(\mathrm{~d}, J=8.5 \mathrm{~Hz}, 4 \mathrm{H}), 6.66(\mathrm{~d}, J=8.5 \mathrm{~Hz}, 4 \mathrm{H}), 6.56(\mathrm{~d}, J=3.5 \mathrm{~Hz}, 2 \mathrm{H}), 5.97(\mathrm{~d}$, $J=3.5 \mathrm{~Hz}, 2 \mathrm{H}), 3.69(\mathrm{~s}, 6 \mathrm{H}), 0.17(\mathrm{~s}, 18 \mathrm{H}) \mathrm{ppm} .{ }^{13} \mathrm{C} \mathrm{NMR}\left(125 \mathrm{MHz}, \mathrm{CDCl}_{3}\right): \delta=160.3$, 159.2, 158.3, 133.2, 132.6, 131.4, 120.8, 112.9, 111.2, 55.1, -1.7 ppm. HRMS (ESI-TOF): calcd for $\mathrm{C}_{30} \mathrm{H}_{37} \mathrm{O}_{4} \mathrm{Si}_{2}: 517.2225[\mathrm{M}+\mathrm{H}]^{+}$; found 517.2217.

\section{bis-Spiroketals 6a and $\mathrm{b}$}
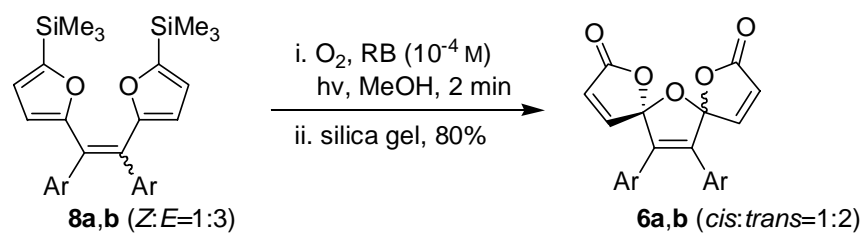

Alkenes 8a and $\mathbf{8 b}(20 \mathrm{mg}, 0.038 \mathrm{mmol})$, as a mixture or separately, were dissolved in methanol $(5 \mathrm{~mL})$ containing Rose Bengal $\left(10^{-4} \mathrm{M}\right)$. Oxygen was gently bubbled through the solution while 
it was irradiated with a xenon Variac Eimac Cermax $300 \mathrm{~W}$ lamp for 2 min $0{ }^{\circ} \mathrm{C}$. After this time complete consumption of the starting alkenes (8a and $\mathbf{8 b}$ ) was observed by TLC. The solvent was removed in vaсиo and the residue passed through a short pad of silica (hexane:ethyl acetate = $1: 3)$ to afford a mixture of $\mathbf{6 a}$ and $\mathbf{6 b}(13 \mathrm{mg}, 80 \%, \mathbf{6 a : 6 \mathbf { b }}=1: 2)$. Isomers $\mathbf{6 a}$ and $\mathbf{6 b}$ were separated by flash column chromatography (silica gel, hexane:ethyl acetate $=1: 1$ ). $\mathbf{6 b}$ : less polar isomer, ${ }^{1} \mathrm{H}$ NMR $\left(500 \mathrm{MHz}, \mathrm{CDCl}_{3}\right): \delta=7.23(\mathrm{~d}, J=5.5 \mathrm{~Hz}, 2 \mathrm{H}), 7.09(\mathrm{~d}, J=8.5 \mathrm{~Hz}, 4 \mathrm{H}), 6.77$ $(\mathrm{d}, J=8.5 \mathrm{~Hz}, 4 \mathrm{H}), 6.21(\mathrm{~d}, J=5.5 \mathrm{~Hz}, 2 \mathrm{H}), 3.77(\mathrm{~s}, 6 \mathrm{H}) \mathrm{ppm} .{ }^{13} \mathrm{C} \mathrm{NMR}\left(125 \mathrm{MHz}, \mathrm{CDCl}_{3}\right): \delta$ $=169.4,160.2,151.7,136.4,129.9,124.7,121.6,116.3,114.4,55.2$ ppm. HRMS (ESI-TOF): calcd for $\mathrm{C}_{24} \mathrm{H}_{19} \mathrm{O}_{7}: 419.1125[\mathrm{M}+\mathrm{H}]^{+}$; found 419.1122. 6a: more polar isomer, ${ }^{1} \mathrm{H}$ NMR (500 $\left.\mathrm{MHz}, \mathrm{CDCl}_{3}\right): \delta=7.22(\mathrm{~d}, J=5.5 \mathrm{~Hz}, 2 \mathrm{H}), 7.06(\mathrm{~d}, J=8.5 \mathrm{~Hz}, 4 \mathrm{H}), 6.76(\mathrm{~d}, J=8.5 \mathrm{~Hz}, 4 \mathrm{H})$, $6.29(\mathrm{~d}, J=5.5 \mathrm{~Hz}, 2 \mathrm{H}), 3.76(\mathrm{~s}, 6 \mathrm{H}) \mathrm{ppm} .{ }^{13} \mathrm{C} \mathrm{NMR}\left(125 \mathrm{MHz}, \mathrm{CDCl}_{3}\right): \delta=168.9,160.1$, 150.6, 137.1, 130.1, 125.7, 121.7, 115.2, 114.2, 55.2 ppm. HRMS (ESI-TOF): calcd for $\mathrm{C}_{24} \mathrm{H}_{19} \mathrm{O}_{7}$ : $419.1125[\mathrm{M}+\mathrm{H}]^{+}$; found 419.1127. 
(2) Copies of Relevant Spectra for 6a, 6b, 8a, 8b, 9, and 10
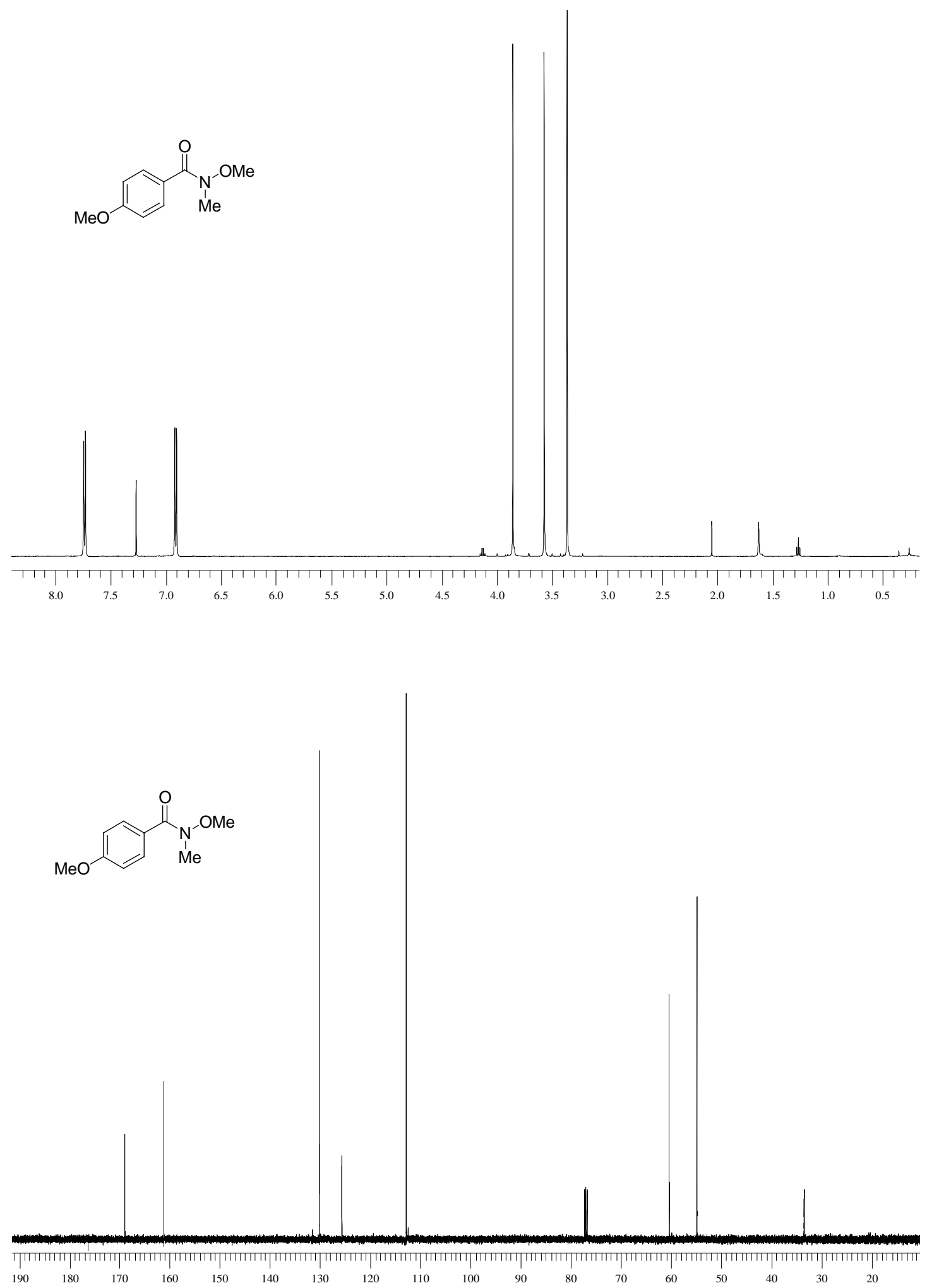

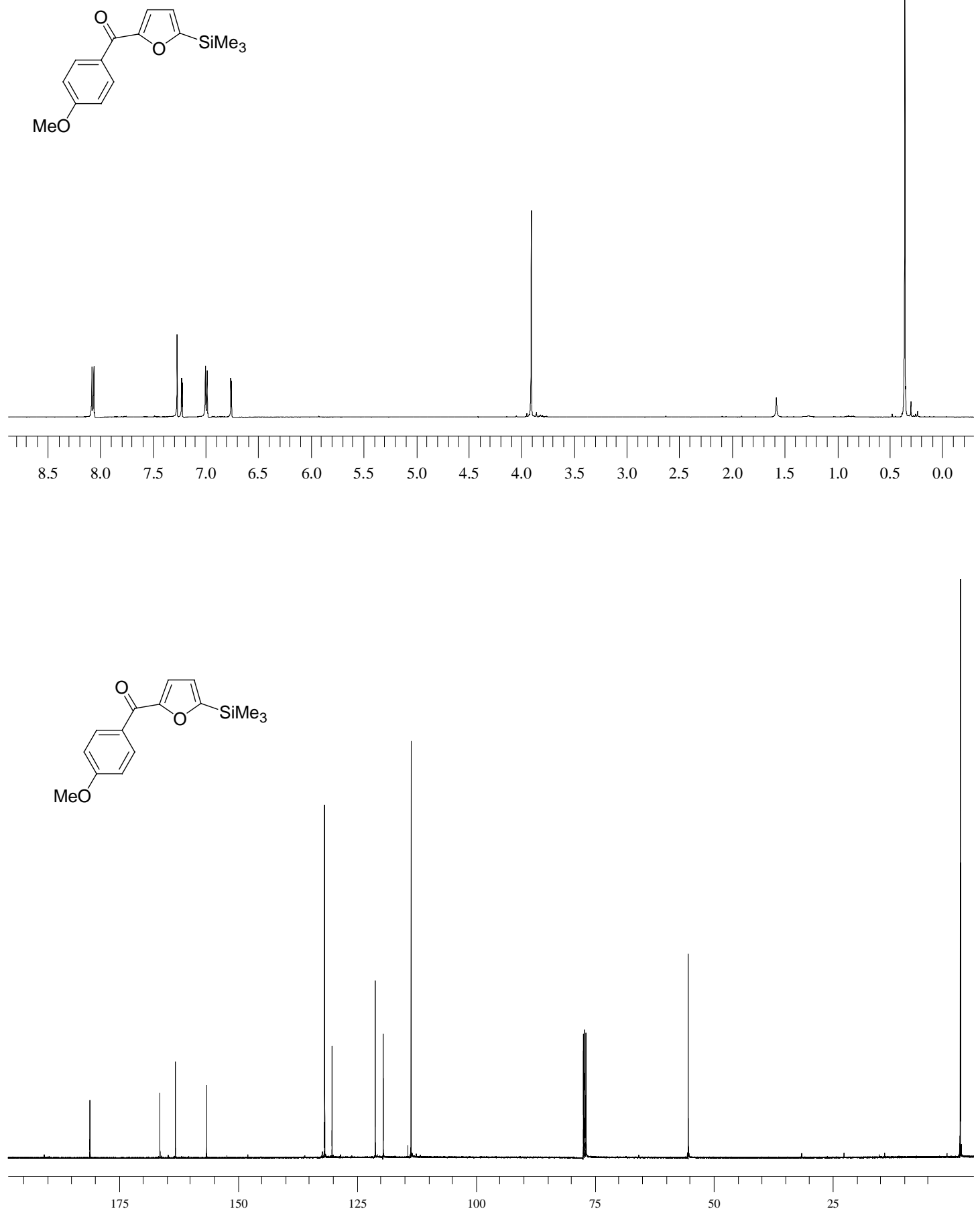

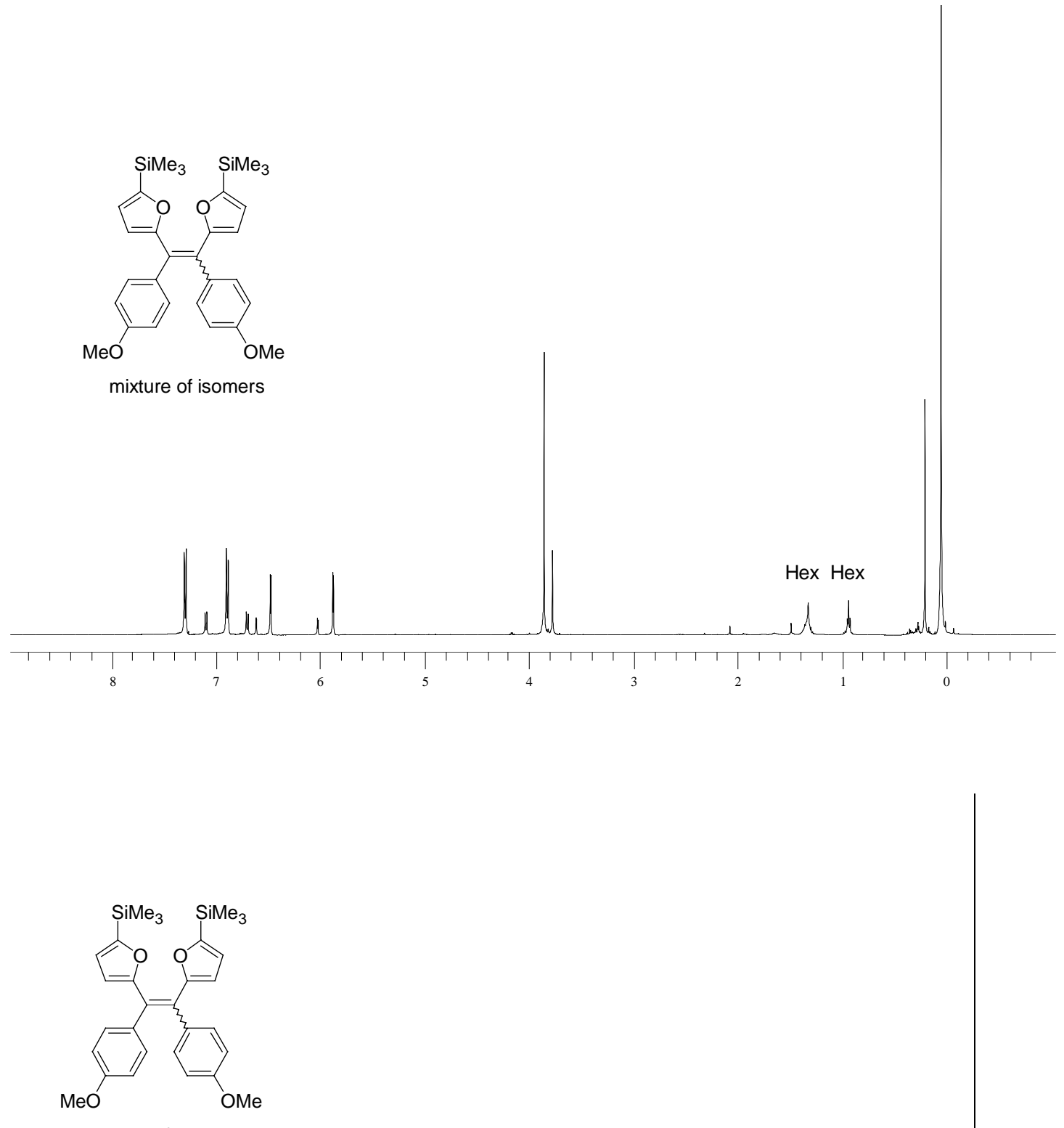

mixture of isomers

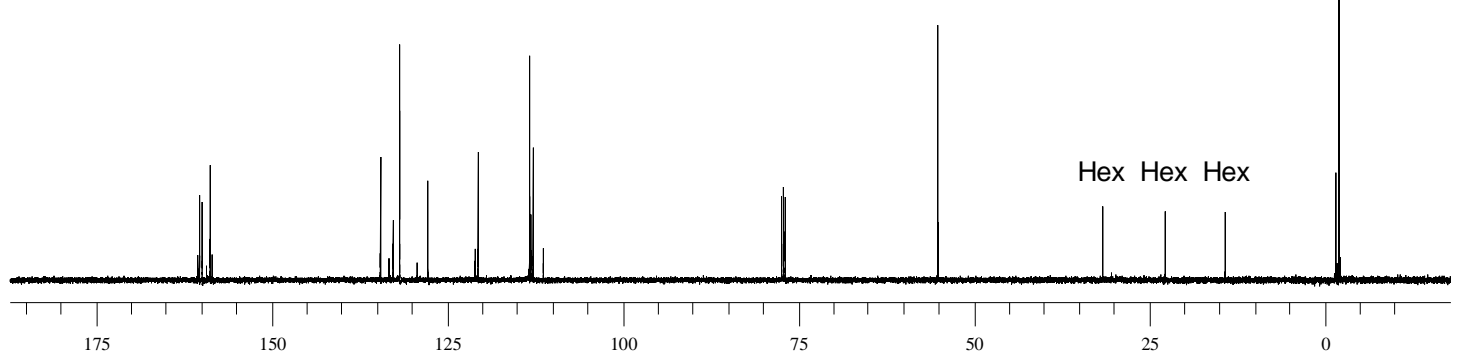



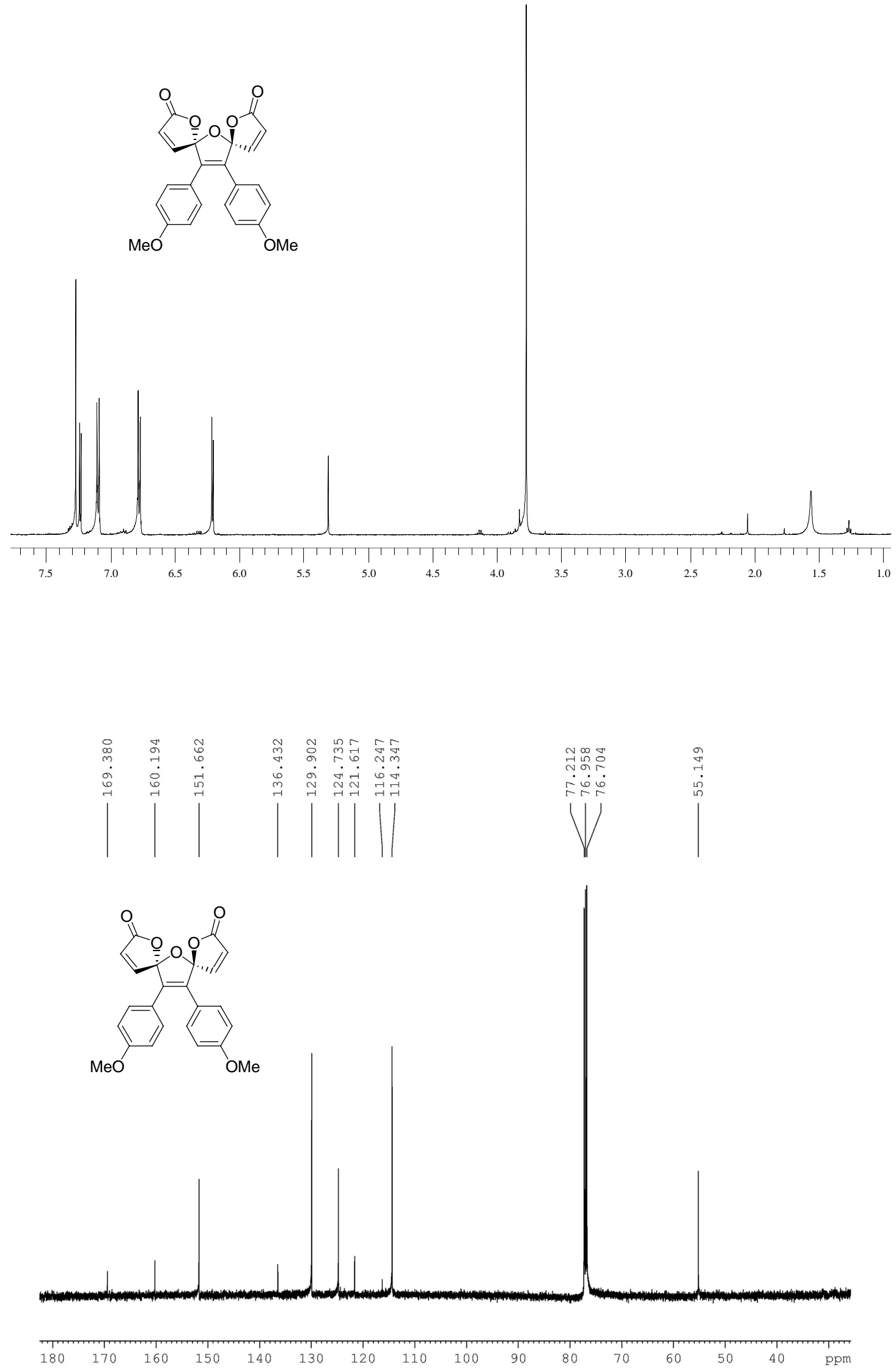

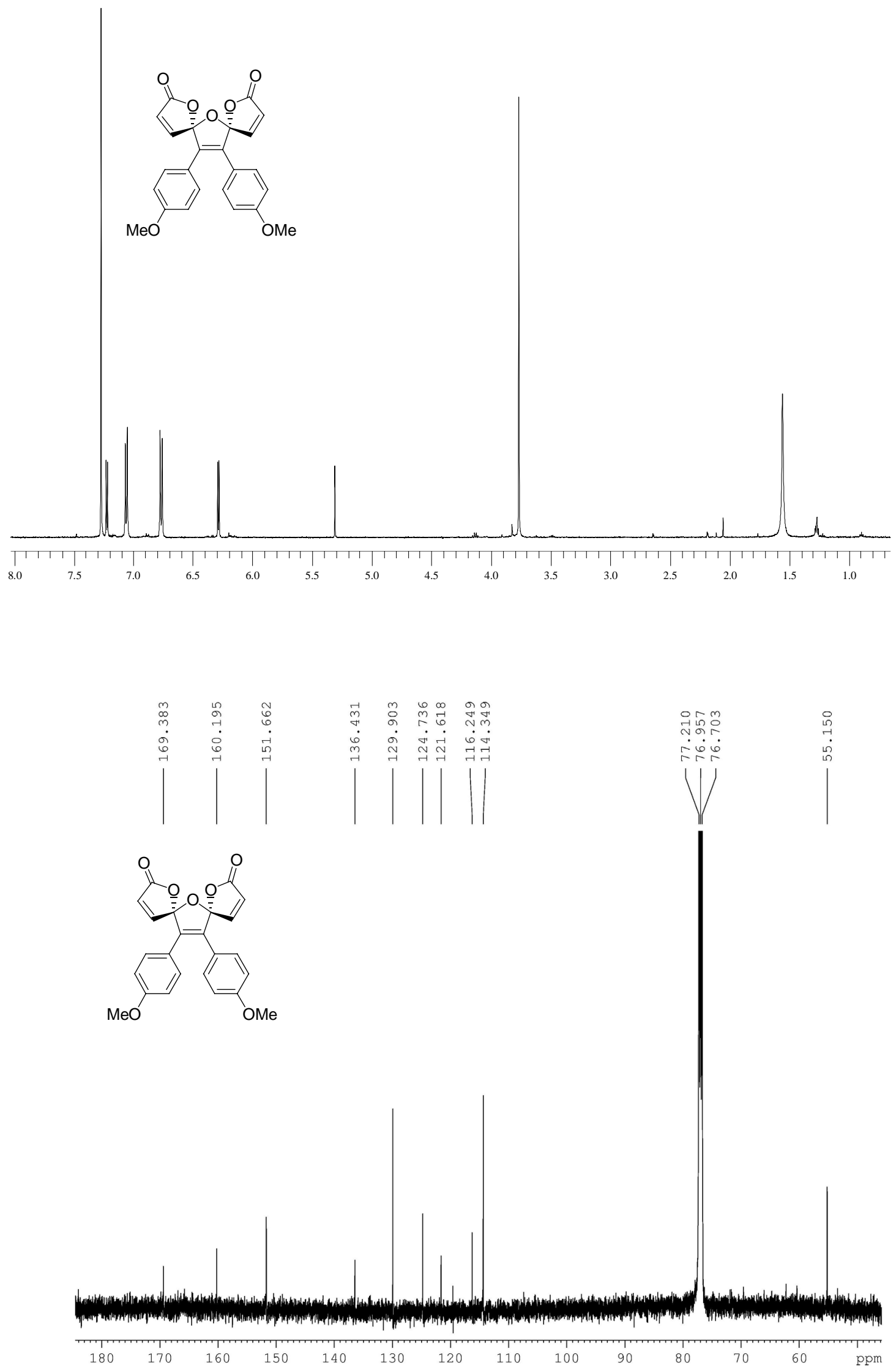